\title{
Curcumin decreases malignant characteristics of glioblastoma stem cells via induction of reactive oxygen species
}

\author{
Zachary C. Gersey ${ }^{1}$, Gregor A. Rodriguez ${ }^{1}$ Eric Barbarite', Anthony Sanchez ${ }^{1}$, Winston M. Walters ${ }^{1}$, \\ Kelechi C. Ohaeto ${ }^{1}$, Ricardo J. Komotar ${ }^{1}$ and Regina M. Graham ${ }^{1,2^{*}}$
}

\begin{abstract}
Background: Glioblastoma Multiforme (GBM) is the most common and lethal form of primary brain tumor in adults. Following standard treatment of surgery, radiation and chemotherapy, patients are expected to survive 12-14 months. Theorized cause of disease recurrence in these patients is tumor cell repopulation through the proliferation of treatment-resistant cancer stem cells. Current research has revealed curcumin, the principal ingredient in turmeric, can modulate multiple signaling pathways important for cancer stem cell self-renewal and survival.

Methods: Following resection, tumor specimens were dissociated and glioblastoma stem cells (GSCs) were propagated in neurosphere media and characterized via immunocytochemistry. Cell viability was determined with MTS assay. GSC proliferation, sphere forming and colony forming assays were conducted through standard counting methods. Reactive oxygen species (ROS) production was examined using the fluorescent molecular probe CMH2DCFA. Effects on cell signaling pathways were elucidated by western blot.

Results: We evaluate the effects of curcumin on patient-derived GSC lines. We demonstrate a curcumin-induced dosedependent decrease in GSC viability with an approximate $I_{50}$ of $25 \mu \mathrm{M}$. Treatment with sub-toxic levels $(2.5 \mu \mathrm{M})$ of curcumin significantly decreased GSC proliferation, sphere forming ability and colony forming potential. Curcumin induced ROS, promoted MAPK pathway activation, downregulated STAT3 activity and IAP family members. Inhibition of ROS with the antioxidant N-acetylcysteine reversed these effects indicating a ROS dependent mechanism.
\end{abstract}

Conclusions: Discoveries made in this investigation may lead to a non-toxic intervention designed to prevent recurrence in glioblastoma by targeting glioblastoma stem cells.

Keywords: Glioblastoma, Stem cell, STAT3, Curcumin, Reactive oxygen species, Brain tumor, Natural product

\section{Background}

Glioblastoma multiforme (GBM) is the most common and deadly primary malignant brain tumor. GBM comprises about $15 \%$ of all intracranial tumors in adults ages 40-75 [1]. The tumor is exceptionally aggressive, with a mean survival of less than 15 months and a 5-year survival rate of $9.8 \%$ after standard therapy of resection, radiation and temozolomide chemotherapy [2, 3]. Despite numerous efforts, there has been stagnation in the

\footnotetext{
*Correspondence: rgraham@med.miami.edu

'Department of Neurosurgery, University of Miami Miller School of Medicine, Miami, Florida, USA

${ }^{2}$ Department of Neurological Surgery, University of Miami Brain Tumor Initiative (UMBTI) Research Laboratory, Lois Pope LIFE Center, 2nd Floor, 1095 NW 14th Terrace, Miami, Florida 33136, USA
}

advancement in treatment of this disease. The lack of improvement in survival rates of glioblastoma has led to the identification of novel therapeutic mechanisms such as targeting cancer stem cells (CSCs), also known as tumor initiating cells or cancer stem-like cells, in order to eradicate this lethal disease.

CSCs are small subset of cells within tumors that have stem-cell-like characteristics that allow them to sustain and repopulate the cancer [4]. The unique qualities of CSCs allow them to evade the chemotherapy and radiation that destroys the bulk of the tumor, eventually leading to the recurrence of disease. This idea has led researchers in search for targeted therapies that will eliminate CSCs and therefore prevent the relapse of cancer 
[4]. A compound that has shown promising anti-CSC properties is the natural phenol curcumin.

Curcumin is the principal curcuminoid in the Indian plant turmeric that has been used for thousands of years in Asian medicine to treat inflammatory conditions. Curcumin has also been shown to have antineoplastic properties including inhibition of proliferation, inducing apoptosis, inhibiting invasion and metastasis and decreasing angiogenesis in multiple tumors including glioblastoma [5-8]. Specifically, curcumin targets CSCs in vitro and in vivo in several cancers, including breast, colorectal, esophageal and glioma [9-13]. It is proposed that these effects are made through curcumin's ability to induce reactive oxygen species [14-20].

Reactive oxygen species (ROS) are natural products formed by the metabolism of oxygen whose regulation plays an essential role in normal cell signaling and homeostasis [21]. The dysregulation of ROS has been implicated in many diseases such as dementia, cardiovascular disease, as well as cancer [22-24]. Current research also suggests that ROS have anti-neoplastic effects on CSCs and that these effects are brought about through the modulation of several molecular pathways including Mitogen-activated protein kinases (MAPKs) and Janus kinas (JAK)- Signal Transducer and Activator of Transcription (STAT3) signaling cascades [25-32]. Aberrations of the MAPKs and JAK-STAT3 pathways have been shown to be critical in the tumorgenesis and maintenance of GBM [33-37].

In this study, we assess the effects of curcumin on glioblastoma stem cells (GSCs) and propose the molecular mechanisms behind such effects.

\section{Methods}

\section{Cells and cell culture}

Human Glioblastoma Multiforme (GBM) tissue was obtained from five adult patients from the University of Miami Department of Neurosurgery diagnosed with WHO-IV gliomas based on the World Health Organization (WHO) classification of tumors of the Central Nervous System. Patients or guardians provided written informed consent prior to tumor sample retrieval. Samples were named Glio3, Glio4, Glio9, Glio11 and Glio14. GBM stemlike cell lines were generated as previously described [38]. Briefly, tumors were mechanically and enzymatically dissociated, red blood cells were removed using Red Cell Lysis buffer (SigmaAldrich, St. Louis, MO), Cells were filtered and plated in a 3:1 ratio of Dulbecco's Modified Eagle's medium (DMEM): F12 (Gibco, Carlsbad, Ca) media supplemented with $1 \%$ penicillin and streptomcycin (penn/ strep), $20 \mathrm{ng} / \mathrm{ml}$ each of human epidermal growth factor and human fibroblast growth factor, and $2 \%$ Gem $21 \mathrm{Ne}-$ uroPlex Serum-Free Supplement (Gemini Bioscience, Sacramento, CA); a formulation consistent for the generation of neurospheres. The GBM cell lines U87, U251 and U235 were purchased from ATCC (Manassas, VA) and were maintained in RPMI media supplemented with $10 \%$ FBS and 1\% penn/strep. These established GBM cell lines grew in an adherent fashion. All cell lines were routinely tested for mycoplasma using LookOut mycoplasma PCR detection kit (SigmaAldrich, St. Louis, MO) according to the manufacturer's instructions and were maintained at $37^{\circ} \mathrm{C}$ in a humidified $5 \% \mathrm{CO}_{2}$ incubator.

\section{Immunofluorescence}

To evaluate stem cell marker expression, neurospheres were dissociated mechanically or enzymatically with Accutase (Gemini Bioscience, Sacramento, CA). To facilitate adherence, cells were plated on poly-L-lysine/ laminin coated four-well plates in neurosphere media. Cells were fixed in $4 \%$ paraformaldehyde, blocked and permeabilized with a $5 \%$ bovine serum albumin (BSA) with $0.6 \%$ Triton $-x 100$ and then treated with the primary antibodies Nestin (Abcam, Cambridge, MA), Sox2, Musashi 1, CD44, Bmi-1 (Cell Signaling Technology, Danvers, MA), CD133 (Biorbyt, Cambridge, UK) and A2B5 (A2B5 clone 105, ATCC, Manassas, VA). A "no primary control" was included for all antibodies tested for all cell lines. For these, the cells were incubated with only the antibody diluent (2.5\% BSA, $0.3 \%$ triton, balance PBS). Cells were then treated with a fluorochromeconjugated secondary antibody followed by Prolong Gold Antifade Reagent with DAPI (Thermo Fisher Scientific, Waltham, MA). Samples were examined under an EVOS FLoid Cell Imaging Station fluorescent microscope (Thermo Fisher Scientific, Waltham, MA).

\section{MTS assay}

Viability was determined using the CellTiter $96^{\circ}$ AQueous One Solution Cell Proliferation Assay (MTS) assay (Promega Madison, WI). Cells were seeded into 96-well plates using a modified neurosphere media containing $5 \% \mathrm{FBS}$ at a density of 10,000 cells per well in $100 \mu \mathrm{l}$ of cell culture media. Following treatment, media was aspirated and $100 \mu \mathrm{l}$ of a 1:5 solution of MTS to cell culture media was added to each well and incubated for 1-4 h. Optical density was measured at $490 \mathrm{~nm}$ using BoiTek Synergy HT plate reader. To examine the effect of temozolomide (Sigma-Aldrich, St. Louis, MO), GBM stem cells were treated with $100 \mu \mathrm{M}$ for $72 \mathrm{~h}$ or U87 cells were treated with $10-100 \mu \mathrm{M}$. Data is represented as the average of 3 separate experiments in which the viability was calculated as the percent of non-treated cells. To determine the effect of curcumin, cells were treated with increasing concentrations of curcumin (Sigma-Aldrich, St. Louis, $\mathrm{MO}$ ) for $72 \mathrm{~h}$. The $\mathrm{IC}_{50}$, the concentration of curcumin at which $50 \%$ of cells were non-viable, was 
determined for a minimum of 3 separate experiments. Data is presented as the average $\mathrm{IC}_{50}$ for each cell line examined.

\section{Proliferation assay}

To determine the effect on cell proliferation 100,000 cells were plated in $10 \mathrm{ml}$ of neurosphere media (100 mm dish for Glio9, and T25 flask for Glio3). Curcumin was added at a concentration of $2.5 \mu \mathrm{M}$ on day 0 . Cells were counted on days 4, 7 and 10 using Orflo Technologies Cell Counter Moxi z (Ketchum, ID). Experiments were done in triplicate.

\section{Sphere forming assay}

The effect of curcumin on clonogenic growth potential was determined using sphere-forming assays. Single cells were seeded at 50-100 cells per well in a 96-well plate and treated with $2.5 \mu \mathrm{M}$ of curcumin on day 0 . Spheres were manually counted under microscopy on day 14 . All experiments were done in triplicate.

\section{Colony forming assay}

Colony counting was performed to determine colony forming potential of the adherent GSC line. Cells were plated at 200 cells per well in 6-wells plates and treated with $2.5 \mu \mathrm{M}$ of curcumin at day 0 . Colonies were stained with $0.01 \%$ crystal violet (Sigma-Aldrich, St. Louis, MO) and counted under microscopy on day 14. Cell clusters of less than 50 cells were not considered colonies and therefore were not counted. Experiments were done in triplicate.

\section{ROS assay}

Curcumin-induced ROS was visualized and quantitated using the general oxidative stress indicator CMH2DCFDA (Thermo Fisher Scientific, Waltham, MA). CM-H2DCFDA passively diffuses into cells and reacts with ROS to yield a fluorescent adduct. For quantification, cells were split into 96-well plates in cell culture media with the addition of 5\% FBS to cause adherence to the well bottoms. Samples were treated with $25 \mu \mathrm{M}$ of curcumin in phenol red free media for $30 \mathrm{~min}, 4 \mathrm{~h}$, and $24 \mathrm{~h}$. Cells were incubated with $0.5 \mu \mathrm{M} \mathrm{CM}$ H2DCFDA in PBS for 5 min subsequently washed in PBS and read at an excitation of $495 \mathrm{~nm}$ and an emission of $525 \mathrm{~nm}$ using BoiTek Synergy HT plate reader. Data is presented as fold change from non-treated cells. Curcumin-induced ROS activity was also examined using fluorescent microscopy. Dissociated GSCs were plated in neurosphere media on poly-L-lysine/laminin coated four-well plates. CM-H2DCFDA fluorescence was evaluated at 1,6 and $24 \mathrm{~h}$ post curcumin $(25 \mu \mathrm{M})$ treatment. Images were obtained using the EVOS FLoid Cell Imaging Station fluorescent microscope (Thermo Fisher Scientific, Waltham, MA).

\section{Western blot analysis}

Neurospheres cultures, Glios 3, 4, 11 and 14 were plated and treated as neurospheres ranging in size from 100$300 \mu \mathrm{m}$ as determined by light microscopy. At 8 or $24 \mathrm{~h}$ of treatment, the effect of curcumin, $\mathrm{N}$-acetylcysteine (NAC, Sigma-Aldrich, St. Louis, MO) or the combination of curcumin and NAC on protein levels was determined by western blot analysis.

Our method for western blot analysis has previously described [39]. Briefly, GSCs were lysed in RIPA buffer, protein concentrations determined by using BCA protein assay and $20 \mu \mathrm{g}$ of protein was loaded onto 8,12 or $15 \%$ polyacrylamide gel (BioRad Hercules, CA) gels for electrophoresis and subsequently transferred onto nitrocellulose membranes. The membranes were then blocked for $1 \mathrm{~h}$ in $5 \%$ non-fat milk (Biorad, Hercules, $\mathrm{CA}$ ) at room temperature (RT) and incubated with the primary antibody diluted in $2.5 \%$ BSA overnight. All primary antibodies were purchased from Cell Signaling (Danvers, MA) except for alpha-tubulin, which was purchased from Abcam (Cambridge, UK) and STAT3, which was purchased from Santa Cruz Biotechnology (Dallas, TX). Membranes were then incubated at room temperature with anti-mouse or anti-rabbit secondary antibodies for $1 \mathrm{~h}$. Blots were developed using SuperSignal $^{\text {mit }}$ West Pico Chemiluminescent Substrate (Thermo Scientific Waltham, MA).

\section{Statistical analysis}

Significance was determined using Student's t-tests for all pairwise comparisons of the different treatments that were tested. The results are presented as the mean \pm standard error mean (SEM). Significance was set at $p<0.05$.

\section{Results}

\section{Human GBM-derived cell lines display cancer stem cell} characteristics

In neurosphere media four out of five cell lines formed spheres, where as the Glio9 grew in an adherent fashion (Fig. 1a). Since there is no definitive marker for GBM stem cells, we examined the expression of multiple putative cancer stem cell markers by immunocytochemistry [40-45]. Except for Glio9 the cell lines demonstrated expression of all markers examined (Fig. 1a). Negative controls for each antibody are shown in Additional file 1: Figure S1A. No SOX2 expression was observed in Glio9. Recently it has been shown that GBM stem cells can be further classified into subgroups, proneural and mesenchymal. These differ both morphologically (neurosphere verse a more adherent phenotype) and in stem cell marker expression [46]. The adherent fashion and the lack of SOX2 expression suggests that glio9 falls into the mesenchymal subgroup. In order to determine if our patient derived cell lines exhibited the cancer stem cell 


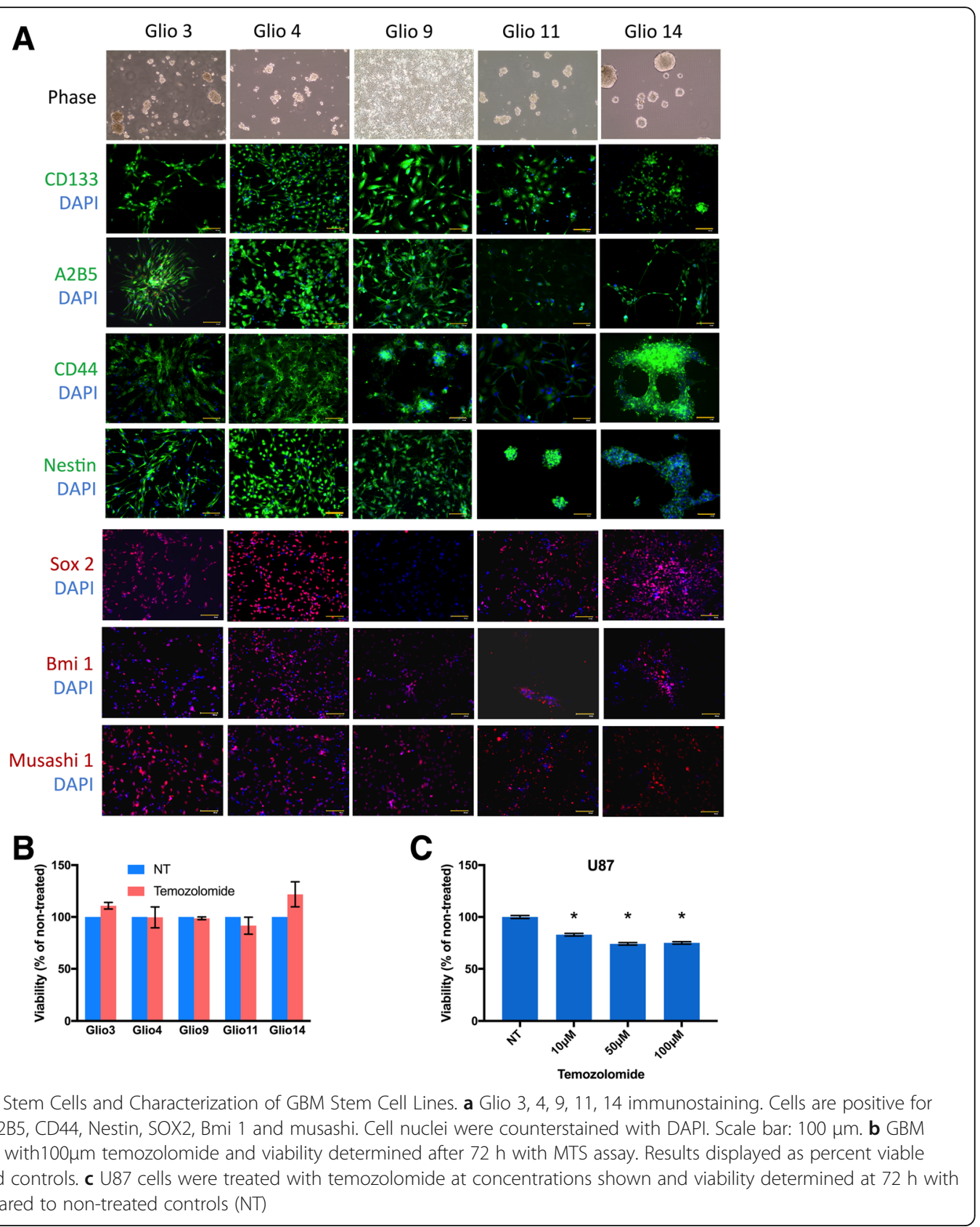

property of chemoresistance [47], we treated five cell lines with $100 \mu \mathrm{M}$ temozolomide, the chemotherapeutic agent of choice for GBM. We chose a concentration of $100 \mu \mathrm{M}$ since this is well above the reported (approximately $10 \mu \mathrm{M}$ ) peak levels in cerebral spinal fluid and brain tissue of treated GBM patients [48, 49]. Our results demonstrate that temozolomide had no significant effect on the viability of these GBM cell lines compared to nontreated controls (Fig. 1b). In contrast, the non-GBM stem cell line U87 was sensitive to temozolomide treatment at doses as low as $10 \mu \mathrm{M}$, the lowest dose examined (Fig. 1c). These data suggest that our patient-derived GBM cell lines demonstrate progenitor cell properties consistent with glioblastoma stem cells (GSCs).

\section{Curcumin decreases viability of glioblastoma stem cells} and non-stem cells

Several reports have demonstrated that curcumin has anti-neoplastic effects on glioblastoma cells [9, 50-52]. To determine the effect of curcumin on GSC viability we treated five GSC cell lines with increasing concentrations of curcumin for $72 \mathrm{~h}$. In all cell lines analyzed, curcumin demonstrated a does-dependent decrease in viability (Fig. 2a). All cell lines reached levels less than 

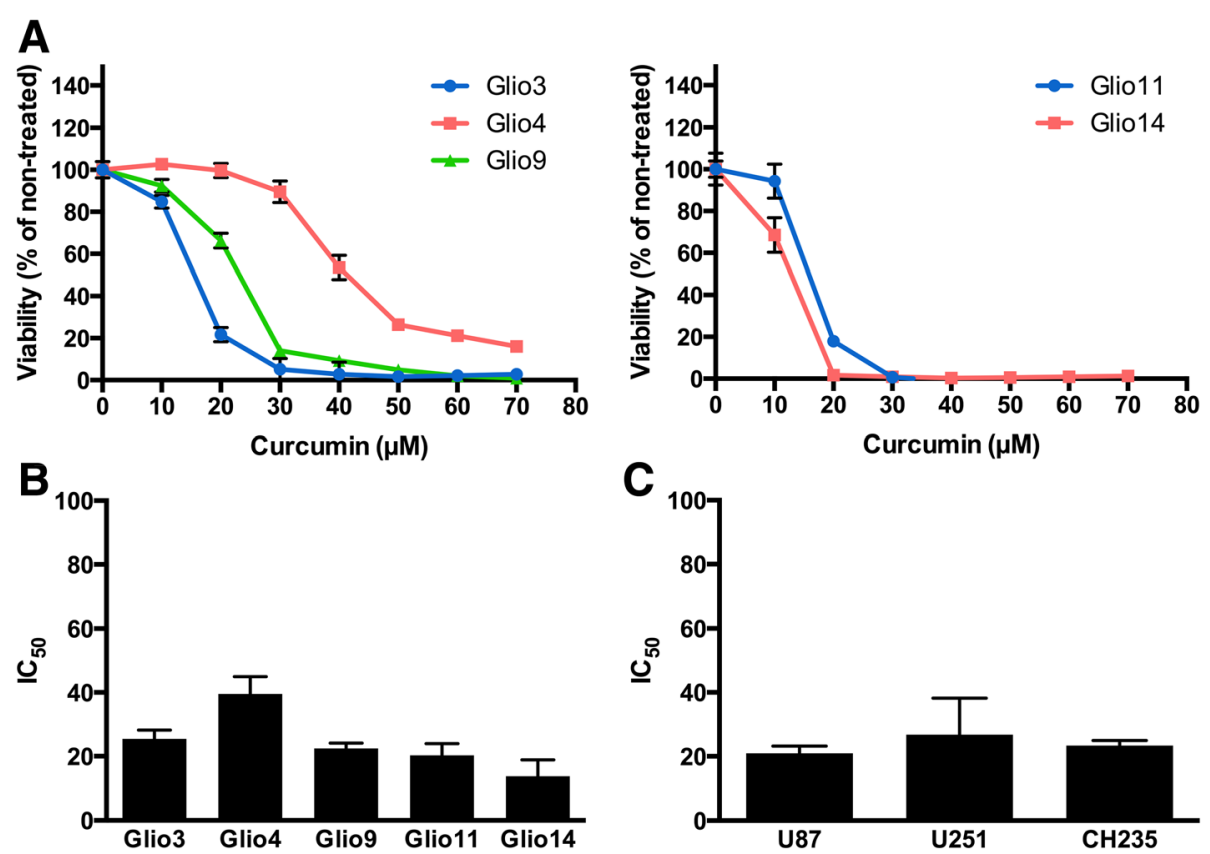

Fig. 2 Effect of curcumin on GBM Stem Cell Lines and non-stem Cell Lines. a GBM stem cells were treated with increasing concentrations of curcumin and viability was assessed $72 \mathrm{~h}$ later with MTS assay. $\mathbf{b}$ MTS viability assay was used to determine concentrations needed to induce $50 \%$ cell death $\left(I C_{50}\right)$ in GBM stem cell lines. c MTS viability assay was used to determine concentrations needed to induce $50 \%$ cell death $\left(I C_{50}\right)$ in GBM non-stem cell lines

$20 \%$ viability at $70 \mu \mathrm{M}$ curcumin-the highest concentration tested. The concentration of curcumin at which $50 \%$ of cells were non-viable is known as the $\mathrm{IC}_{50}$. The $\mathrm{IC}_{50}$ S were as follows: Glio3 $25.5 \mu \mathrm{M}$ (SEM: $\left.2.7 \mu \mathrm{M}\right)$, Glio4 $39.5 \mu \mathrm{M}$ (SEM: 5.4 $\mu \mathrm{M}$ ), Glio9 $22.5 \mu \mathrm{M}$ (SEM: $1.7 \mu \mathrm{M}$ ), Glio11 $20.3 \mu \mathrm{M}$ (SEM: $3.7 \mu \mathrm{M}$ ), and Glio14 $13.9 \mu \mathrm{M}$ (SEM: $5.0 \mu \mathrm{M}$ ) (Fig. $2 \mathrm{~b}$ ). We also verified that curcumin decreases the viability of GBM non-stem cells using the established GBM cell lines U87, U251 and $\mathrm{CH} 235$. The $\mathrm{IC}_{50} \mathrm{~s}$ of these common GBM cell lines were $30.0 \mu \mathrm{M}$ (SEM: $2.2 \mu \mathrm{M}$ ) for U87, $26.8 \mu \mathrm{M}$ (SEM: $11.5 \mu \mathrm{M})$ for $\mathrm{U} 251$, and $23.4 \mu \mathrm{M}$ (SEM: $1.6 \mu \mathrm{M})$ for $\mathrm{CH} 235$ (Fig. 2c). Taken together, these results show that curcumin has a does-dependent effect on the viability of both GBM stem cells and non-stem cells.

\section{Curcumin inhibits proliferation, sphere-forming ability} and colony-forming potential of glioblastoma stem cells Cancer stem cells are marked by their ability to proliferate indefinitely and by their sphere- and colony-forming potential at the single cell level in vitro [53, 54]. We chose to carry out the remainder of the experiments in this study using Glio3, a non-adherent GSC cell line, and Glio9, an adherent GSC cell line, due to their similar $\mathrm{IC}_{50} \mathrm{~S}$ and differing adherence patterns. In order to determine if curcumin affects the proliferative ability of GSCs, we plated Glio3 and Glio9 at $1 \times 10^{5}$ cells and treated with $2.5 \mu \mathrm{M}$ curcumin on day 0 . Curcumin treated Glio3 showed a statistically significant decrease in cell number on days 7 and $10(p<0.05)$ compared to non-treated controls, whereas Glio9 showed a non-significant decrease in cell number on days 7 and 10 (Fig. 3a). To investigate whether curcumin has an effect on the sphere-forming capacity of GSCs, we seeded the nonadherent cell line Glio3 at 50-100 cells per well and treated it with $2.5 \mu \mathrm{M}$ curcumin on day 0 . Spheres were counted on day 14. Glio3 demonstrated a $60 \%$ decrease in sphere formation when treated with curcumin compared to non-treated controls $(p<0.05)$ (Fig. 3b). The adherent cell line Glio9 was used to determine if curcumin affects the colony-forming ability of GSCs. Glio 9 was plated at 200 cells per well and $2.5 \mu \mathrm{M}$ curcumin was treated at day 0 . On day 14, the curcumin treated cells showed a dramatic $95 \%$ reduction in colony number compared to non-treated controls $(p<0.05)$ (Fig. 3c). These data show that low doses of curcumin inhibit proliferation, sphere-forming and colony-forming potentials of GSCs.

\section{Curcumin induces ROS in glioblastoma stem cells}

Curcumin has been demonstrated to induce reactive oxygen species (ROS) in various cancer cell lines [55-57]. To determine if curcumin has the same effect on GSCs we used the molecular probe CM-H2DCFDA, a general oxidative stress indicator, to measure ROS via fluorescence in two cell lines. Under fluorescence microscopy, Glio9 


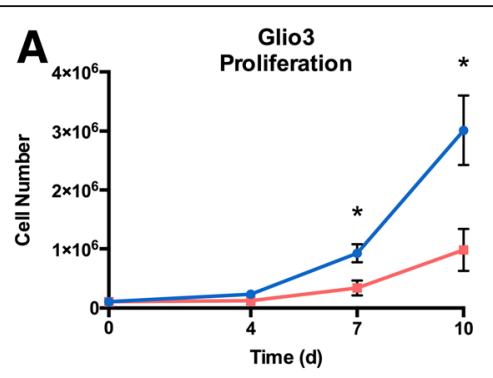

B Sphere Formation

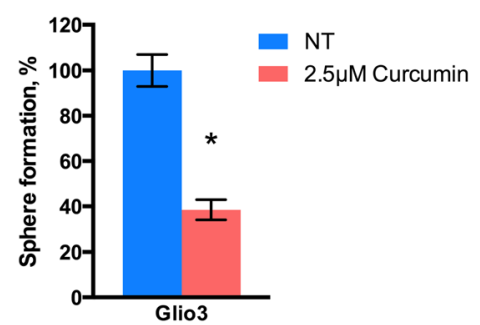

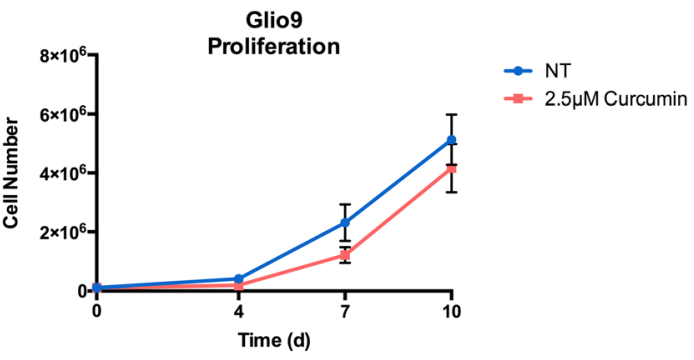

C Colony Formation

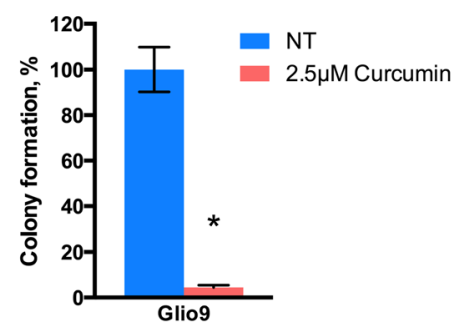

Fig. 3 Curcumin decreases proliferation, sphere forming ability and colony forming potential in GSC cell lines. a Glio3 and Glio9 GSCs were plated at $1 \times 10^{5}$ cells initially and treated with $2.5 \mu \mathrm{M}$ curcumin on day 0. Cells were counted using Orflo Technologies Cell Counter Moxi z on days 4, 7 and 10. b Glio3 GSCs were seeded at 50-100 cells per well in a 96-well plate and treated with $2.5 \mu$ M curcumin on day 0 . Spheres were counted on day 14. c Glio9 GSCs were plated at 200 cells and treated with $2.5 \mu \mathrm{M}$ curcumin at day 0. Colonies were stained with crystal violet and counted on day $14 .{ }^{*} p<0.05$, non-treated controls (NT) vs. curcumin treated

showed an induction of ROS at the 1 and $6 \mathrm{~h}$ time points after treatment with $25 \mu \mathrm{M}$ curcumin with a return to control levels at $24 \mathrm{~h}$ (Fig. 4a). After quantification, a one time treatment of $25 \mu \mathrm{M}$ curcumin was shown to significantly induce ROS in Glio3 and Glio9 with a peak increase of approximately 6-8 fold relative fluorescence at $4 \mathrm{~h}$ post-treatment relative to non-treated controls $(p<0.05)$. ROS were shown to decrease $24 \mathrm{~h}$ post-treatment (Fig. $4 \mathrm{~b}$ ). These data suggest that curcumin may cause its effects in GSCs via induction of ROS.

\section{Curcumin induces MAPK activation, inactivates STAT3 and downregulates the STAT3 downstream target Survivin in glioblastoma stem cells}

Studies have demonstrated that ROS can induce the activation of multiple signaling pathways including the MAPK pathways in several cell types $[58,59]$. We used western blot analysis to determine curcumin's, and potentially ROS activation's, modulation on different signaling pathways. Following $8 \mathrm{~h}$ of $25 \mu \mathrm{M}$ curcumin treatment, the phosphorylated (activated) form of ERK, p38 and cjun (as an indicator of JNK activation) was increased in the GSCs Glio3 and Glio9 (Fig. 5a). This was also demonstrated in all other GSC cell lines (Additional file 2: Figure S2), ERK has been shown to cause the repression of STAT3 activity via dephosphorylation at the Tyr705 position and phosphorylation at the Ser727 location [60]. Here we show that treatment with curcumin decreases the Tyr705 phosphorylated form of STAT3 and increases the Ser727 form in Glio3 and Glio9 (Fig. 5b). When STAT3 is dephosphorylated at the Tyr705 position and phosphorylated at the Ser727 position it is rendered inactive and is incapable of translocating to the nucleus to carry out its downstream effects. We also demonstrate the decreased expression of STAT3's downstream target Survivin as well as the other anti-apoptosis proteins IAP1 and IAP2 (Glio9 only) in these GSCs (Fig. 5c). These results suggest that curcumin induces the activation of MAPKs and the inhibition of STAT3 activity in GSCs.

\section{$\mathrm{N}$-acetylcysteine rescues curcumin-induced effects on glioblastoma stem cells}

$\mathrm{N}$-acetylcysteine (NAC) is an antioxidant shown to decrease ROS [61, 62]. To test whether ROS induction was truly the mechanism for curcumin's anti-malignant effects on GSCs, we conducted a cell viability assay and western blot analysis to determine if NAC could rescue curcumin's effects on GSCs. We treated cells with $5 \mathrm{mM}$ NAC, $25 \mu \mathrm{M}$ curcumin, and a combination of both treatments and viability was determined at $72 \mathrm{~h}$. Treatment with NAC alone had no significant effect on viability on all cell lines except for Glio4, which showed an 18.7\% increase in viability $(p<0.05)$. Treatment with curcumin alone showed significant decreases in viability in all cell lines compared to non-treated controls $(p<0.001)$. When cells were pretreated with NAC to prevent ROS induction, cell viability was significantly rescued in all cell lines compared to curcumin only treated cells $(p<0.001)$ (Fig. 6a). To determine if NAC treatment reverses curcumin's effects on signaling pathways in Glio3 and Glio9, cells were treated 


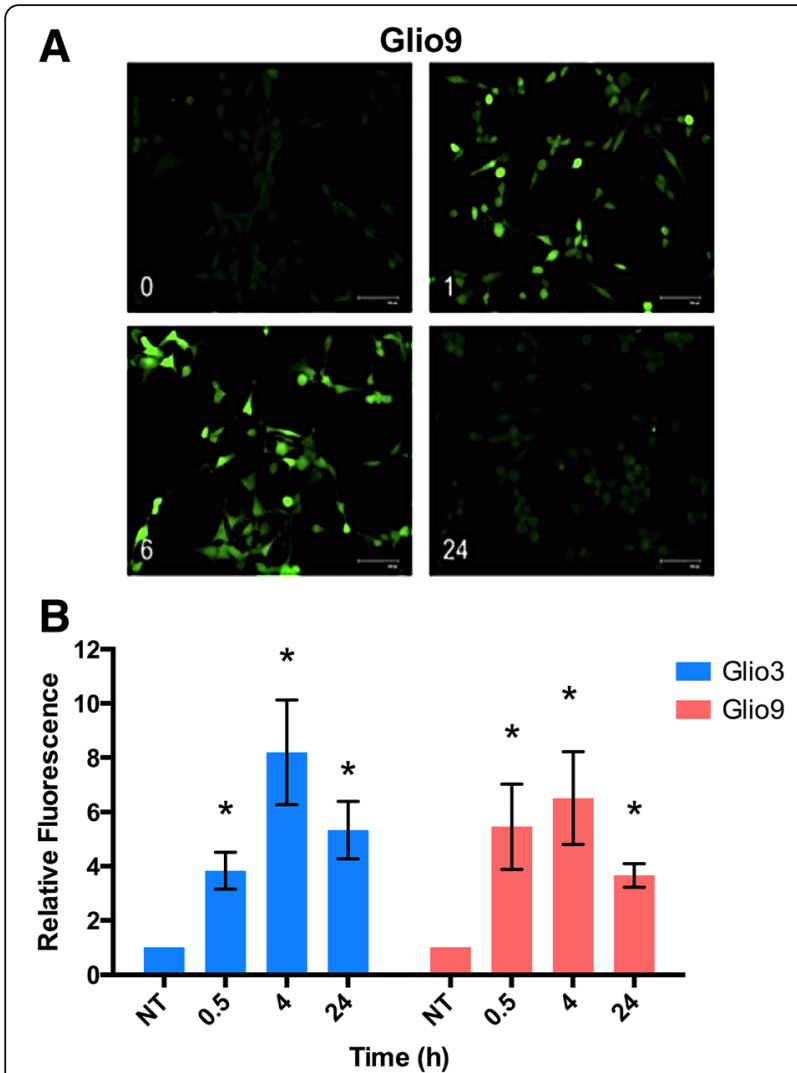

Fig. 4 Curcumin induces reactive oxygen species activation in GSCs. a Curcumin-mediated ROS induction in the GSC glio9 was visualized using CM-H2DCFDA, which produces $s$ a fluorescent adduct (green) in the presence of ROS, at 0, 1, 6 and $24 \mathrm{~h}$ under fluorescent microscopy. b ROS induction in the GSC glio3 and glio9 at 0, 0.5, 4 and $24 \mathrm{~h}$ following curcumin treatment was determined by measuring CM-H2DCFDA fluorescent intensities in a microplate reader. Data expressed as fold change over non-treated (NT) controls. ${ }^{*} p<0.05$ compared to NT

with $5 \mathrm{mM}$ NAC, $25 \mu \mathrm{M}$ curcumin, and a combination of both treatments for $8 \mathrm{~h}$. Western blot analysis indicates that NAC reversed the curcumin-induced MAPK activation (Fig. 6b) and STAT3 deactivation-signified by an increase in p-STAT3 (Tyr705) and a decrease in p-STAT3 (Ser727) (Fig. 6c). This was also demonstrated in all GSC cell lines at the Tyr705 position (Additional file 3: Figure S3). These data demonstrate that ROS induction may be the mechanism behind curcumin's anti-cancer effects.

\section{Discussion}

A growing body of evidence indicates that GSCs are responsible for tumor formation, progression and recurrence and that targeting these cells may be paramount in the eradication of GBM [63, 64]. Studying GSCs from patient derived GBM samples is the best model of disease in humans, as it has been shown that established, indefinitely passaged GBM cell lines do not predict clinical drug efficacy and are not representative of patient tumors [65]. Here we demonstrate the anti-neoplastic

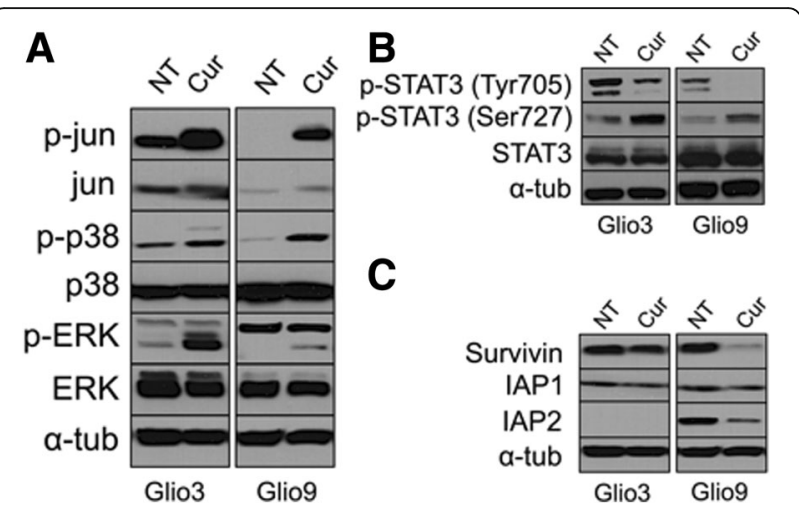

Fig. 5 The effects of curcumin on molecular pathways. a Expression of p-jun, jun, p-p38, p38, p-ERK and ERK were assessed by western blot analysis in non-treated (NT) GSCs and $8 \mathrm{~h}$ after $25 \mu \mathrm{M}$ of curcumin. b Expression of p-STAT3 (Tyr705), p-STAT3 (Ser727) and STAT3 was assessed by western blot analysis in non-treated GSCS (NT) GSCs and $8 \mathrm{~h}$ after $25 \mu \mathrm{M}$ of curcumin. c Expression of the anti-apoptosis proteins Survivin, IAP1 and IAP2 were assessed in non-treated GSCs and $24 \mathrm{~h}$ after $25 \mu \mathrm{M}$ of curcumin. Alpha-tubulin was used as a loading control for experiments $\mathbf{a}-\mathbf{c}$

effects of curcumin, a blood brain barrier permeable compound shown to be non-toxic to normal astrocytes and neurons, on patient derived GSCs $[66,67]$.

In this study we demonstrate through a neurosphere growth pattern (with the exception of the adherent Gio9), chemoresistance and the expression of all tested stem cell markers (with the exception of SOX2 in Glio9) in all cell lines that our samples are indeed GSCs (Fig. 1). Due to its adherent nature and lack of SOX2 expression, we hypothesize that Glio9 is of the mesenchymal GBM subtype $[46,68]$. We show that curcumin decreases viability of GSCs in a dose dependent manner (Fig. 2) and that low doses of curcumin inhibit proliferation, sphere formation and colony formation of GSCs (Fig. 3). Experiments at doses this low are lacking from the GBM literature. We have shown that treatment with curcumin induces ROS activity (Fig. 4) and that pretreatment with the antioxidant n-acetylcysteine reverses curcumin's effects on viability and molecular pathways (Fig. 6). It has been shown that the ERK pathway is inducible through ROS $[58,59]$ and that activated ERK can cause repression of STAT3 and downregulation of its downstream targets though an inhibition of its tyrosine 705 phosphorylation and activation of its serine 727 phosphorylation [60]. Although more work needs to be done, our data suggests that curcumin may exert its effects through this mechanism via induction of ROS.

The role of ROS in cancer is dichotomist in nature. Low levels of ROS have been shown to promote cancer through stimulation of cell proliferation, increased cell survival and amplified angiogenesis through activation of several pathways including NF-kB [69-71]. High levels 


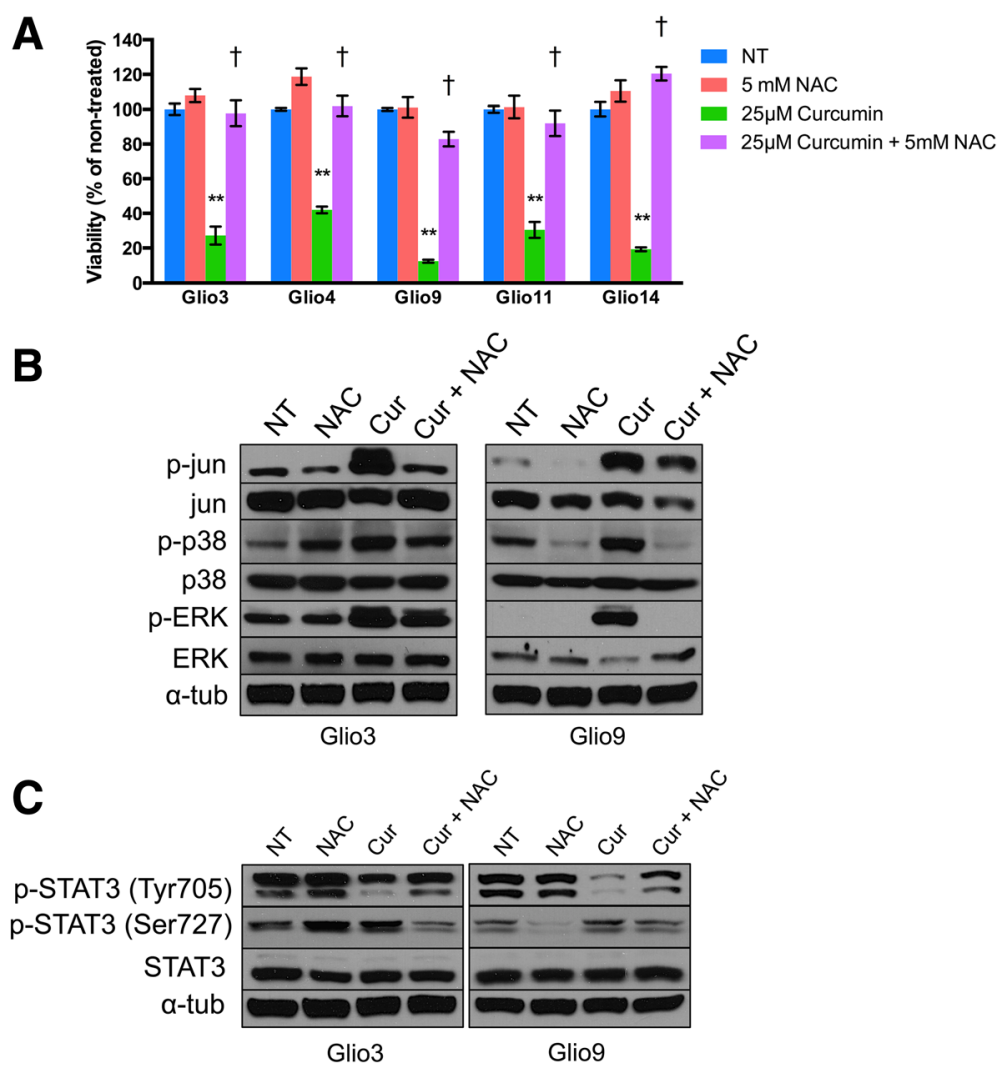

Fig. $6 \mathrm{~N}$-acetylcysteine (NAC) rescues curcumin-induced decrease in viability and modulation of molecular pathways in multiple GSC cell lines. a GSCs were treated with $5 \mathrm{mM}$ NAC alone, $25 \mathrm{uM}$ curcumin alone or $5 \mathrm{mM}$ NAC and $25 \mathrm{uM}$ curcumin in combination. Viability was assessed at $72 \mathrm{~h}$ using the MTS assay. Results displayed as percent viable cells compared to untreated controls (NT). $\mathbf{b}$ Expression of p-jun, jun, p-p38, p38, pERK and ERK was assessed in non-treated (NT), $5 \mathrm{mM}$ NAC treated, $25 \mu \mathrm{M}$ curcumin treated, and pretreated $5 \mathrm{mM}$ NAC followed by $25 \mu \mathrm{M}$ curcumin treated GSCs after 8 h. c Expression of p-STAT3 (Tyr705), p-STAT3 (Ser727) and STAT3 was assessed in non-treated (NT), 5 mM NAC treated, 25 M curcumin treated, and pretreated $5 \mathrm{mM}$ NAC followed by $25 \mu \mathrm{M}$ curcumin treated GSCs after $8 \mathrm{~h}$. Alpha-tubulin was used as a loading control. ${ }^{*} P<0.001$ vs. NT. $+P<0.001$ vs. $25 \mu \mathrm{M}$ Curcumin

of ROS have been shown to have anti-cancer effects by inducing cell cycle arrest and apoptosis via several mechanisms including Rac-1/NADPH oxidase pathway induction [72, 73]. CSCs have been shown to have lower intracellular ROS content due to increased expression of free radical scavenging systems [74]. Although this may indicate CSC ROS resistance, several studies have demonstrated ROS-induced targeting of CSCs. Induction of ROS through niclosamide treatment in AML, parthenolide treatment in AML and CML, and arsenic trioxide treatment in PML (promyelocytic leukemia) target CSCs [75-77]. In this study we demonstrate that curcumininduced ROS targets glioblastoma stem cells.

Curcumin has been shown to be an effective CSC targeting molecule in glioma as well as other tumor types [9-12] while maintaining a minimal side effect profile even at high doses of $12 \mathrm{~g} /$ day [78]. The main hurdle facing curcumin as a potential chemotherapeutic agent is its bioavailability [14]. When dosed orally, unformulated curcumin has been shown to reach peak plasma levels of
$<2 \mu \mathrm{M}$ in humans [79]. In order to overcome this limitation, researchers have formulated several bioavailable forms of curcumin. Nano-emulsion curcumin, thermacurcumin (curcumin within colloidal nanoparticles), and curcumin within $\mathrm{N}$-trimethyl chitosan coated solid lipid nanoparticles have been shown to reach peak plasma levels of $12.6 \mu \mathrm{M}, 4.6 \mu \mathrm{M}$, and $3.28 \mu \mathrm{M}$ respectively in rodent models [80-82]. In this study we demonstrate that $2.5 \mu \mathrm{M}$ of curcumin inhibits the self-renewal properties of GSCs. In order to target GSC viability at curcumin levels of $25 \mu \mathrm{M}$ (Fig. 6) and above, alternative routes of administration must be considered. Polymeric drug and convection-enhanced delivery systems have been shown to deliver high local concentrations of active agents while decreasing systemic toxicities in GBM and may serve to circumvent the bioavailability issues facing curcumin [83]. Currently curcumin is being evaluated clinically for neurological diseases including bi-polar disorder and Alzheimer's disease as well as for multiple cancers, however clinical trials are needed to determine 
the potential of curcumin alone and in combination with radiotherapy and or chemotherapy for GBM patients.

\section{Conclusions}

In summary, we have found that curcumin targets glioblastoma stem cells though the induction of ROS, potentially through downregulation of STAT3 activity. The importance of STAT3 in GBM has previously been described [84]. Specifically, inhibition of STAT3 signaling decreased GSC survival both in culture and in orthotopic xenograft models [85]. Furthermore, levels of STAT3's downstream target, Survivin correlate with astrocytoma grade and may be predictive of poor patient survival $[86,87]$. We show that low doses of curcumin inhibit the self-renewal properties of GSCs-an important characteristic for a chemotherapy targeting GBM relapse-and that curcumin decreases GSC viability in a dose dependent manner. These findings indicate that curcumin may be a safe future chemotherapeutic agent for the treatment of glioblastoma and further studies are warranted.

\section{Additional files}

Additional file 1: Figure S1. No primary controls for stem cell immunofluorescence shown in Fig. 1a. For control staining, antibody diluent without primary antibody was used, followed by the secondary antibody. Cells were counterstained with DAPI to identify nucleus. No stem cell marker fluorescence was observed in control cells. Scale bar: $100 \mu \mathrm{m}$. (TIFF $1896 \mathrm{~kb}$ )

Additional file 2: Figure S2. The effects of curcumin on MAPKs in additional GBM stem cell lines. Expression of p-jun, jun, p-p38, p38, p-ERK and ERK were assessed by western blot analysis in non-treated (NT) GSCs and $8 \mathrm{~h}$ after $25 \mu \mathrm{M}$ of curcumin. Alpha-tubulin was used as a loading control for all experiments. (TIFF $562 \mathrm{~kb}$ )

Additional file 3: Figure S3. N-acetylcysteine (NAC) rescues curcumininduced p-STAT3 (Tyr705) activation in additional GBM stem cell lines. Ex pression of p-STAT3 (Tyr705) and STAT3 was assessed in non-treated (NT) $5 \mathrm{mM}$ NAC treated, $25 \mu \mathrm{M}$ curcumin treated, and pretreated $5 \mathrm{mM}$ NAC followed by $25 \mu \mathrm{M}$ curcumin treated GSCs after $8 \mathrm{~h}$. Alpha-tubulin was used as a loading control. (TIFF $345 \mathrm{~kb}$ )

\section{Abbreviations \\ AML: Acute myeloid leukemia; ATCC: American type culture collection; BCA: Bicinchoninic acid; BSA: Bovine serum albumin; CML: Chronic myeloid leukemia; DAPI: 4',6-diamidino-2-phenylindole; DMEM: Dulbecco's modified Eagle's medium; ERK: Extracellular signal-regulated kinases; FBS: Fetal bovine serum; GBM: Glioblastoma multiforme; GSCs: Glioblastoma stem cells; IAP: Inhibitor of apoptosis protein; JAK: Janus kinase; JNK: Jun N-terminal ki- nases; MAPK: Mitogen-activated protein kinases; NAC: N-acetylcysteine; NADPH: Nicotinamide adenine dinucleotide phosphate; NF-kB: Nuclear factor kappa-light-chain-enhancer of activated B cells; PCR: Polymerase chain reaction; PML: Promyelocytic leukemia; Rac-1: Ras-related C3 botulinum toxin substrate 1; ROS: Reactive oxygen species; RPMI: Roswell Park Memorial Institute; SEM: Standard error of the mean; STAT3: Signal transducer and activator of transcription 3; WHO: World health organization}

\section{Acknowledgements}

We would like to thank our wonderful laboratory volunteers Beatriz Hawkins, Amelia Bahamonde, Nicolas de Cordoba and Sumedh Shah for their contributions to our research efforts.

\section{Funding}

University of Miami Brain Tumor Initiative (UMBTI) and the Mystic Force Foundation provided salary support for RMG and cost of all materials/ reagents required for this work.

\section{Availability of data and materials}

The authors declare that the data supporting the findings of this study are available within the article and its supplementary information files.

\section{Authors' contributions}

ZCG conducted experiments, analyzed data and contributed to writing the manuscript. GAR conducted experiments and analyzed data. ERB conducted experiments and analyzed data. AS conducted experiments and analyzed data. WMW conducted experiments and analyzed data. KCO conducted experiments. RJK analyzed data and contributed to writing the manuscript. RMG conducted experiments, analyzed data and contributed to writing the manuscript. All authors read and approved the final manuscript.

\section{Competing interests}

The authors declare that they have no competing interests.

\section{Consent for publication}

Not applicable.

\section{Ethics approval and consent to participate}

All human samples were retrieved after patient or guardian gave written informed consent. All tissue samples were obtained at the University of Miami and were approved by its ethics committee and institutional review board.

Received: 20 October 2016 Accepted: 11 January 2017

Published online: 04 February 2017

\section{References}

1. lacob G, Dinca EB. Current data and strategy in glioblastoma multiforme. J Med Life. 2009;2:386-93.

2. Spratt DE, Folkert M, Zumsteg ZS, Chan TA, Beal K, Gutin PH, Pentsova E, Yamada Y. Temporal relationship of post-operative radiotherapy with temozolomide and oncologic outcome for glioblastoma. J Neurooncol. 2014:116:357-63.

3. Sundar SJ, Hsieh JK, Manjila S, Lathia JD, Sloan A. The role of cancer stem cells in glioblastoma. Neurosurg Focus. 2014;37:E6.

4. Tan BT, Park CY, Ailles LE, Weissman IL. The cancer stem cell hypothesis: a work in progress. Lab Invest. 2006:86:1203-7.

5. Perry MC, Demeule M, Regina A, Moumdjian R, Beliveau R. Curcumin inhibits tumor growth and angiogenesis in glioblastoma xenografts. Mol Nutr Food Res. 2010;54:1192-201.

6. Liao H, Wang Z, Deng Z, Ren H, Li X. Curcumin inhibits lung cancer invasion and metastasis by attenuating GLUT1/MT1-MMP/MMP2 pathway. Int J Clin Exp Med. 2015;8:8948-57.

7. Sobolewski C, Muller F, Cerella C, Dicato M, Diederich M. Celecoxib prevents curcumin-induced apoptosis in a hematopoietic cancer cell model. Mol Carcinog. 2015:54:999-1013.

8. Zhang X, Wang R, Chen G, Dejean L, Chen QH. The Effects of Curcuminbased Compounds on Proliferation and Cell Death in Cervical Cancer Cells. Anticancer Res. 2015;35:5293-8

9. Hossain M, Banik NL, Ray SK. Synergistic anti-cancer mechanisms of curcumin and paclitaxel for growth inhibition of human brain tumor stem cells and LN18 and U138MG cells. Neurochem Int. 2012;61:1102-13.

10. Almanaa TN, Geusz ME, Jamasbi RJ. Effects of curcumin on stem-like cells in human esophageal squamous carcinoma cell lines. BMC Complement Altern Med. 2012;12:195.

11. Lin L, Liu Y, Li H, Li PK, Fuchs J, Shibata H, Iwabuchi Y, Lin J. Targeting colon cancer stem cells using a new curcumin analogue, GO-Y030. Br J Cancer. 2011;105:212-20.

12. Charpentier MS, Whipple RA, Vitolo MI, Boggs AE, Slovic J, Thompson KN, Bhandary L, Martin SS. Curcumin targets breast cancer stem-like cells with microtentacles that persist in mammospheres and promote reattachment Cancer Res. 2014;74:1250-60. 
13. Rodriguez GA, Shah AH, Gersey ZC, Shah SS, Bregy A, Komotar RJ, Graham $\mathrm{RM}$. Investigating the therapeutic role and molecular biology of curcumin as a treatment for glioblastoma. Ther Adv Med Oncol. 2016;8:248-60.

14. Shehzad A, Wahid F, Lee YS. Curcumin in cancer chemoprevention: molecular targets, pharmacokinetics, bioavailability, and clinical trials. Arch Pharm (Weinheim). 2010;343:489-99.

15. Padhye S, Chavan D, Pandey S, Deshpande J, Swamy KV, Sarkar FH. Perspectives on chemopreventive and therapeutic potential of curcumin analogs in medicinal chemistry. Mini Rev Med Chem. 2010;10:372-87.

16. Sarkar FH, Li Y, Wang Z, Padhye S. Lesson learned from nature for the development of novel anti-cancer agents: implication of isoflavone, curcumin, and their synthetic analogs. Curr Pharm Des. 2010;16:1801-12.

17. Shehzad A, Lee YS. Molecular mechanisms of curcumin action: signal transduction. Biofactors. 2013;39:27-36.

18. Chang PY, Peng SF, Lee CY, Lu CC, Tsai SC, Shieh TM, Wu TS, Tu MG, Chen MY, Yang JS. Curcumin-loaded nanoparticles induce apoptotic cell death through regulation of the function of MDR1 and reactive oxygen species in cisplatin-resistant CAR human oral cancer cells. Int J Oncol. 2013;43:1141-50.

19. Liu H, Zhou BH, Qiu X, Wang HS, Zhang F, Fang R, Wang XF, Cai SH, Du J, Bu XZ. T63, a new 4-arylidene curcumin analogue, induces cell cycle arrest and apoptosis through activation of the reactive oxygen species-FOXO3a pathway in lung cancer cells. Free Radic Biol Med. 2012;53:2204-17.

20. Chung SS, Vadgama JV. Curcumin and epigallocatechin gallate inhibit the cancer stem cell phenotype via down-regulation of STAT3-NFkappaB signaling. Anticancer Res. 2015;35:39-46.

21. Devasagayam TP, Tilak JC, Boloor KK, Sane KS, Ghaskadbi SS, Lele RD. Free radicals and antioxidants in human health: current status and future prospects. J Assoc Physicians India. 2004;52:794-804.

22. Kaur U, Banerjee P, Bir A, Sinha M, Biswas A, Chakrabarti S. Reactive oxygen species, redox signaling and neuroinflammation in Alzheimer's disease: the NF-kappaB connection. Curr Top Med Chem. 2015;15:446-57.

23. Kornfeld OS, Hwang S, Disatnik MH, Chen CH, Qvit N, Mochly-Rosen D. Mitochondrial reactive oxygen species at the heart of the matter: new therapeutic approaches for cardiovascular diseases. Circ Res. 2015;116:1783-99.

24. Saito S, Lin YC, Tsai MH, Lin CS, Murayama Y, Sato R, Yokoyama KK. Emerging roles of hypoxia-inducible factors and reactive oxygen species in cancer and pluripotent stem cells. Kaohsiung J Med Sci. 2015;31:279-86.

25. Chang Z, Xing J, Yu X. Curcumin induces osteosarcoma MG63 cells apoptosis via ROS/Cyto-C/Caspase-3 pathway. Tumour Biol. 2014;35:753-8.

26. Kaushik G, Kaushik T, Yadav SK, Sharma SK, Ranawat P, Khanduja KL, Pathak CM. Curcumin sensitizes lung adenocarcinoma cells to apoptosis via intracellular redox status mediated pathway. Indian J Exp Biol. 2012;50:853-61.

27. Li PM, Li YL, Liu B, Wang WJ, Wang YZ, Li Z. Curcumin inhibits MHCC97H liver cancer cells by activating ROS/TLR-4/caspase signaling pathway. Asian Pac J Cancer Prev. 2014;15:2329-34

28. Yu T, Ji J, Guo YL. MST1 activation by curcumin mediates JNK activation, Foxo3a nuclear translocation and apoptosis in melanoma cells. Biochem Biophys Res Commun. 2013;441:53-8.

29. Kobayashi $\mathrm{Cl}$, Suda T. Regulation of reactive oxygen species in stem cells and cancer stem cells. J Cell Physiol. 2012;227:421-30.

30. Li X, Wang K, Ren Y, Zhang L, Tang XJ, Zhang HM, Zhao CQ, Liu PJ, Zhang $J M$, He JJ. MAPK signaling mediates sinomenine hydrochloride-induced human breast cancer cell death via both reactive oxygen speciesdependent and -independent pathways: an in vitro and in vivo study. Cell Death Dis. 2014:5:e1356.

31. Jung SN, Shin DS, Kim HN, Jeon YJ, Yun J, Lee YJ, Kang JS, Han DC, Kwon BM. Sugiol inhibits STAT3 activity via regulation of transketolase and ROSmediated ERK activation in DU145 prostate carcinoma cells. Biochem Pharmacol. 2015:97:38-50.

32. Chae IG, Kim DH, Kundu J, Jeong CH, Kundu JK, Chun KS. Generation of ROS by CAY10598 leads to inactivation of STAT3 signaling and induction of apoptosis in human colon cancer HCT116 cells. Free Radic Res. 2014:48:1311-21.

33. Cha JH, Choi YJ, Cha SH, Choi CH, Cho WH. Allicin inhibits cell growth and induces apoptosis in U87MG human glioblastoma cells through an ERKdependent pathway. Oncol Rep. 2012;28:41-8

34. Dutra-Oliveira A, Monteiro RQ, Mariano-Oliveira A. Protease-activated receptor2 (PAR2) mediates VEGF production through the ERK1/2 pathway in human glioblastoma cell lines. Biochem Biophys Res Commun. 2012;421:221-7.

35. Liu Z, Jiang Z, Huang J, Huang S, Li Y, Yu S, Yu S, Liu X. miR-7 inhibits glioblastoma growth by simultaneously interfering with the PI3K/ATK and Raf/MEK/ERK pathways. Int J Oncol. 2014;44:1571-80.
36. Sherry MM, Reeves A, Wu JK, Cochran BH. STAT3 is required for proliferation and maintenance of multipotency in glioblastoma stem cells. Stem Cells. 2009;27:2383-92.

37. Rahaman SO, Harbor PC, Chernova O, Barnett GH, Vogelbaum MA, Haque SJ. Inhibition of constitutively active Stat3 suppresses proliferation and induces apoptosis in glioblastoma multiforme cells. Oncogene. 2002;21:8404-13.

38. Pastori C, Daniel M, Penas C, Volmar CH, Johnstone AL, Brothers SP, Graham RM, Allen B, Sarkaria JN, Komotar RJ, et al. BET bromodomain proteins are required for glioblastoma cell proliferation. Epigenetics. 2014:9:611-20.

39. Graham RM, Hernandez F, Puerta N, De Angulo G, Webster KA, Vanni S. Resveratrol augments ER stress and the cytotoxic effects of glycolytic inhibition in neuroblastoma by downregulating Akt in a mechanism independent of SIRT1. Exp Mol Med. 2016:48:e210.

40. Gotte M, Wolf M, Staebler A, Buchweitz O, Kelsch R, Schuring AN, Kiesel L. Increased expression of the adult stem cell marker Musashi-1 in endometriosis and endometrial carcinoma. J Pathol. 2008;215:317-29.

41. Prince ME, Sivanandan R, Kaczorowski A, Wolf GT, Kaplan MJ, Dalerba P, Weissman IL, Clarke MF, Ailles LE. Identification of a subpopulation of cells with cancer stem cell properties in head and neck squamous cell carcinoma. Proc Natl Acad Sci U S A. 2007;104:973-8.

42. Jin $X$, Jin $X$, Jung JE, Beck S, Kim H. Cell surface Nestin is a biomarker for glioma stem cells. Biochem Biophys Res Commun. 2013;433:496-501.

43. Anido J, Saez-Borderias A, Gonzalez-Junca A, Rodon L, Folch G, Carmona MA, Prieto-Sanchez RM, Barba I, Martinez-Saez E, Prudkin L, et al. TGF-beta Receptor Inhibitors Target the CD44(high)/Id1(high) Glioma-Initiating Cell Population in Human Glioblastoma. Cancer Cell. 2010;18:655-68.

44. Tchoghandjian A, Baeza N, Colin C, Cayre M, Metellus P, Beclin C, Ouafik L, Figarella-Branger D. A2B5 cells from human glioblastoma have cancer stem cell properties. Brain Pathol. 2010;20:211-21.

45. Brescia P, Ortensi B, Fornasari L, Levi D, Broggi G, Pelicci G. CD133 is essential for glioblastoma stem cell maintenance. Stem Cells. 2013;31:857-69.

46. Mao P, Joshi K, Li J, Kim SH, Li P, Santana-Santos L, Luthra S, Chandran UR, Benos PV, Smith L, et al. Mesenchymal glioma stem cells are maintained by activated glycolytic metabolism involving aldehyde dehydrogenase 1A3. Proc Natl Acad Sci U S A. 2013;110:8644-9.

47. Malik B, Nie D. Cancer stem cells and resistance to chemo and radio therapy. Front Biosci (Elite Ed). 2012;4:2142-9.

48. Portnow J, Badie B, Chen M, Liu A, Blanchard S, Synold TW. The neuropharmacokinetics of temozolomide in patients with resectable brain tumors: potential implications for the current approach to chemoradiation Clin Cancer Res. 2009;15:7092-8.

49. Ostermann S, Csajka C, Buclin T, Leyvraz S, Lejeune F, Decosterd LA, Stupp R. Plasma and cerebrospinal fluid population pharmacokinetics of temozolomide in malignant glioma patients. Clin Cancer Res. 2004;10:3728-36.

50. Shi $L$, Fei $X$, Wang Z. Demethoxycurcumin was prior to temozolomide on inhibiting proliferation and induced apoptosis of glioblastoma stem cells. Tumour Biol. 2015;36:7107-19.

51. Zhuang W, Long L, Zheng B, Ji W, Yang N, Zhang Q, Liang Z. Curcumin promotes differentiation of glioma-initiating cells by inducing autophagy. Cancer Sci. 2012;103:684-90.

52. Lim KJ, Bisht S, Bar EE, Maitra A, Eberhart CG. A polymeric nanoparticle formulation of curcumin inhibits growth, clonogenicity and stem-like fraction in malignant brain tumors. Cancer Biol Ther. 2011;11:464-73.

53. Singh SK, Clarke ID, Terasaki M, Bonn VE, Hawkins C, Squire J, Dirks PB. Identification of a cancer stem cell in human brain tumors. Cancer Res. 2003:63:5821-8

54. Lobo NA, Shimono Y, Qian D, Clarke MF. The biology of cancer stem cells. Annu Rev Cell Dev Biol. 2007:23:675-99.

55. Picone P, Nuzzo D, Caruana L, Messina E, Scafidi V, Di Carlo M. Curcumin induces apoptosis in human neuroblastoma cells via inhibition of AKT and Foxo3a nuclear translocation. Free Radic Res. 2014:48:1397-408

56. Rana C, Piplani H, Vaish V, Nehru B, Sanyal SN. Downregulation of PI3-KJAkt/ PTEN pathway and activation of mitochondrial intrinsic apoptosis by Diclofenac and Curcumin in colon cancer. Mol Cell Biochem. 2015;402:225-41.

57. Ko YC, Lien JC, Liu HC, Hsu SC, Ji BC, Yang MD, Hsu WH, Chung JG. Demethoxycurcumin induces the apoptosis of human lung cancer $\mathrm{NCl}$ H460 cells through the mitochondrial-dependent pathway. Oncol Rep. 2015;33:2429-37. 
58. Keshari RS, Verma A, Barthwal MK, Dikshit M. Reactive oxygen speciesinduced activation of ERK and p38 MAPK mediates PMA-induced NETs release from human neutrophils. J Cell Biochem. 2013;114:532-40.

59. McCubrey JA, Lahair MM, Franklin RA. Reactive oxygen species-induced activation of the MAP kinase signaling pathways. Antioxid Redox Signal. 2006:8:1775-89.

60. Jain N, Zhang T, Fong SL, Lim CP, Cao X. Repression of Stat3 activity by activation of mitogen-activated protein kinase (MAPK). Oncogene. 1998;17:3157-67.

61. Zhu Y, Paul P, Lee S, Craig BT, Rellinger EJ, Qiao J, Gius DR, Chung DH Antioxidant inhibition of steady-state reactive oxygen species and cell growth in neuroblastoma. Surgery. 2015;158:827-36.

62. Sun Y, Pu LY, Lu L, Wang XH, Zhang F, Rao JH. N-acetylcysteine attenuates reactive-oxygen-species-mediated endoplasmic reticulum stress during liver ischemia-reperfusion injury. World J Gastroenterol. 2014;20:15289-98.

63. Zhu Z, Khan MA, Weiler M, Blaes J, Jestaedt L, Geibert M, Zou P, Gronych J, Bernhardt O, Korshunov A, et al. Targeting self-renewal in high-grade brain tumors leads to loss of brain tumor stem cells and prolonged survival. Cell Stem Cell. 2014;15:185-98.

64. Chen J, Li Y, Yu TS, McKay RM, Burns DK, Kernie SG, Parada LF. A restricted cell population propagates glioblastoma growth after chemotherapy. Nature. 2012:488:522-6.

65. Lee J, Kotliarova S, Kotliarov Y, Li A, Su Q, Donin NM, Pastorino S, Purow BW, Christopher N, Zhang W, et al. Tumor stem cells derived from glioblastomas cultured in bFGF and EGF more closely mirror the phenotype and genotype of primary tumors than do serum-cultured cell lines. Cancer Cell. 2006;9:391-403.

66. Zanotto-Filho A, Braganhol E, Edelweiss MI, Behr GA, Zanin R, Schroder R, Simoes-Pires A, Battastini AM, Moreira JC. The curry spice curcumin selectively inhibits cancer cells growth in vitro and in preclinical model of glioblastoma. J Nutr Biochem. 2012;23:591-601.

67. Purkayastha S, Berliner A, Fernando SS, Ranasinghe B, Ray I, Tariq H, Banerjee P. Curcumin blocks brain tumor formation. Brain Res. 2009; 1266:130-8

68. Sathyan P, Zinn PO, Marisetty AL, Liu B, Kamal MM, Singh SK, Bady P, Lu L, Wani KM, Veo BL, et al. Mir-21-Sox2 Axis Delineates Glioblastoma Subtypes with Prognostic Impact. J Neurosci. 2015;35:15097-112.

69. Schreck R, Albermann K, Baeuerle PA. Nuclear factor kappa B: an oxidative stress-responsive transcription factor of eukaryotic cells (a review). Free Radic Res Commun. 1992;17:221-37.

70. Rabbani ZN, Spasojevic I, Zhang X, Moeller BJ, Haberle S, Vasquez-Vivar J, Dewhirst MW, Vujaskovic Z, Batinic-Haberle I. Antiangiogenic action of redox-modulating $\mathrm{Mn}$ (III) meso-tetrakis (N-ethylpyridinium-2-yl) porphyrin, MnTE-2-PyP (5+), via suppression of oxidative stress in a mouse model of breast tumor. Free Radic Biol Med. 2009;47:992-1004.

71. Burdon RH, Gill V, Rice-Evans C. Oxidative stress and tumour cell proliferation. Free Radic Res Commun. 1990;11:65-76.

72. Sahu RP, Zhang R, Batra S, Shi Y, Srivastava SK. Benzyl isothiocyanatemediated generation of reactive oxygen species causes cell cycle arrest and induces apoptosis via activation of MAPK in human pancreatic cancer cells. Carcinogenesis. 2009;30:1744-53.

73. Chung YM, Bae YS, Lee SY. Molecular ordering of ROS production, mitochondrial changes, and caspase activation during sodium salicylateinduced apoptosis. Free Radic Biol Med. 2003;34:434-42.

74. Diehn M, Cho RW, Lobo NA, Kalisky T, Dorie MJ, Kulp AN, Qian D, Lam JS, Ailles $L E$, Wong $M$, et al. Association of reactive oxygen species levels and radioresistance in cancer stem cells. Nature. 2009;458:780-3.

75. Ito K, Bernardi R, Morotti A, Matsuoka S, Saglio G, Ikeda Y, Rosenblatt J, Avigan DE, Teruya-Feldstein J, Pandolfi PP. PML targeting eradicates quiescent leukaemia-initiating cells. Nature. 2008;453:1072-8.

76. Guzman ML, Rossi RM, Karnischky L, Li X, Peterson DR, Howard DS, Jordan CT. The sesquiterpene lactone parthenolide induces apoptosis of human acute myelogenous leukemia stem and progenitor cells. Blood. 2005:105:4163-9.

77. Jin Y, Lu Z, Ding K, Li J, Du X, Chen C, Sun X, Wu Y, Zhou J, Pan J. Antineoplastic mechanisms of niclosamide in acute myelogenous leukemia stem cells: inactivation of the NF-kappaB pathway and generation of reactive oxygen species. Cancer Res. 2010;70:2516-27.

78. Lao CD, Ruffin MT, Normolle D, Heath DD, Murray SI, Bailey JM, Boggs ME, Crowell J, Rock CL, Brenner DE. Dose escalation of a curcuminoid formulation. BMC Complement Altern Med. 2006;6:10.
79. Cheng AL, Hsu CH, Lin JK, Hsu MM, Ho YF, Shen TS, Ko JY, Lin JT, Lin BR, Ming-Shiang W, et al. Phase I clinical trial of curcumin, a chemopreventive agent, in patients with high-risk or pre-malignant lesions. Anticancer Res. 2001;21:2895-900

80. Ramalingam P, Ko YT. Enhanced oral delivery of curcumin from N-trimethyl chitosan surface-modified solid lipid nanoparticles: pharmacokinetic and brain distribution evaluations. Pharm Res. 2015;32:389-402.

81. Sasaki H, Sunagawa Y, Takahashi K, Imaizumi A, Fukuda H, Hashimoto T, Wada H, Katanasaka Y, Kakeya H, Fujita M, et al. Innovative preparation of curcumin for improved oral bioavailability. Biol Pharm Bull. 2011;34:660-5.

82. Zhongfa L, Chiu M, Wang J, Chen W, Yen W, Fan-Havard P, Yee LD, Chan KK. Enhancement of curcumin oral absorption and pharmacokinetics of curcuminoids and curcumin metabolites in mice. Cancer Chemother Pharmacol. 2012;69:679-89.

83. Zhou J, Atsina KB, Himes BT, Strohbehn GW, Saltzman WM. Novel delivery strategies for glioblastoma. Cancer J. 2012;18:89-99.

84. Kim JE, Patel M, Ruzevick J, Jackson CM, Lim M. STAT3 Activation in Glioblastoma: Biochemical and Therapeutic Implications. Cancers (Basel). 2014:6:376-95.

85. Stechishin OD, Luchman HA, Ruan Y, Blough MD, Nguyen SA, Kelly JJ, Cairncross JG, Weiss S. On-target JAK2/STAT3 inhibition slows disease progression in orthotopic xenografts of human glioblastoma brain tumor stem cells. Neuro Oncol. 2013;15:198-207.

86. Shirai K, Suzuki Y, Oka K, Noda SE, Katoh H, Suzuki Y, Itoh J, Itoh H, Ishiuchi $\mathrm{S}$, Sakurai $\mathrm{H}$, et al. Nuclear survivin expression predicts poorer prognosis in glioblastoma. J Neurooncol. 2009;91:353-8.

87. Kajiwara Y, Yamasaki F, Hama S, Yahara K, Yoshioka H, Sugiyama K, Arita K, Kurisu K. Expression of survivin in astrocytic tumors: correlation with malignant grade and prognosis. Cancer. 2003;97:1077-83.

\section{Submit your next manuscript to BioMed Central and we will help you at every step:}

- We accept pre-submission inquiries

- Our selector tool helps you to find the most relevant journal

- We provide round the clock customer support

- Convenient online submission

- Thorough peer review

- Inclusion in PubMed and all major indexing services

- Maximum visibility for your research

Submit your manuscript at www.biomedcentral.com/submit
Biomed Central 